Accessed on: http://jkb.ub.ac.id/index.php/jkb/article/view/2649

Jurnal Kedokteran Brawijaya Vol. 31, No. 1, Februari 2020, pp. 28-32

Article History: Received 23 Oktober 2019, Accepted 9 Januari 2020

$\underline{\text { Research Article }}$

\title{
Analysis of Lamina Papyracea Area and Ethmoid Sinus Volume in Indonesian Patients Undergoing Paranasal Sinus CT Scan
}

\section{Analisis Luas Lamina Papyracea dan Volume Sinus Ethmoid pada Pasien Orang Indonesia yang Dilakukan Pemeriksaan CT Scan Sinus Paranasalis}

\author{
Wahyuni ${ }^{1}$, Nurlaily Idris ${ }^{2}$, Mirna Muis ${ }^{3}$, Andi Alfian Ż, Muhammad Fadjar P ${ }^{5}$, Muhammad llyas ${ }^{6}$ \\ ${ }_{1,2,3,6}$ Department of Radiology Faculty of Medicine Universitas Hasanuddin Makassar \\ ${ }^{4}$ Department of Public Health/Family Medicine Faculty of Medicine Universitas Hasanuddin Makassar \\ ${ }^{5}$ Department of Health Sciences ENT-KL Faculty of Medicine Universitas Hasanuddin Makassar
}

\begin{abstract}
Of the rhinosinusitis (CRS) patients, half of whom require surgical intervention. Functional endoscopic sinus surgery (FESS) is a standard treatment of CRS and sinonasal polyposis. Orbito-ocular complications can occur during FESS. The lamina papyracea $(L P)$ is the weakest point of the medial wall of the orbit. The variability in the size and shape of the paranasal sinuses is important in the FESS procedure. The ethmoid sinus is the most complex paranasal sinuses. Preoperative evaluation using computed tomography (CT) is mandatory for all patients undergoing FESS. This study aimed to determine the lamina papyracea area and ethmoid sinuses volume in patients who underwent a CT scan of paranasal sinuses. This study was a descriptive study on 103 patients who underwent a CT scan of paranasal sinuses in the Radiology Department of Hasanuddin University General Hospital, Makassar, from January to August 2019. The lamina papyracea area and ethmoid sinus volume were measured based on age and gender. The results showed that the average of lamina papyracea size and ethmoid sinus volume was greater in males than in females. There was a correlation between age and posterior height of left lamina papyracea ( $p=0.02)$, but no correlation between ethmoid sinuses volume and age.
\end{abstract}

Keywords: Ethmoid sinus volume, lamina papyracea area, paranasal sinus CT scan

\begin{abstract}
ABSTRAK
Rhinosinusitis (CRS) pada 50\% pasien memerlukan intervensi bedah. Bedah sinus endoskopi fungsional (FESS) merupakan penanganan standar CRS dan poliposis sinonasal. Komplikasi orbito-okular dapat terjadi selama FESS. Lamina papyracea (LP) merupakan titik terlemah dari medial orbit. Variabilitas ukuran dan bentuk sinus paranasal penting dalam prosedur FESS. Sinus ethmoid merupakan sinus paranasal yang paling kompleks. Evaluasi praoperasi oleh computed tomography (CT) wajib untuk semua pasien yang menjalani FESS. Penelitian ini bertujuan untuk mengetahui luas /amina papyracea dan volume sinus ethmoid pada pasien yang dilakukan pemeriksaan CT scan sinus paranasalis. Penelitian ini merupakan penelitian deskriptif terhadap 103 pasien yang dilakukan pemeriksaan CT scan sinus paranasalis di Departemen Radiologi RSUP Universitas Hasanuddin Makassar periode Januari-Agustus 2019. Peneliti mengukur luas lamina papyracea dan volume sinus ethmoid berdasarkan usia dan jenis kelamin. Hasil penelitian menunjukkan rata-rata ukuran lamina papyracea dan volume sinus ethmoid laki-laki lebih besar dari perempuan. Terdapat korelasi antara usia dan tinggi posterior lamina papyracea kiri $(p=0,02)$. Namun, tidak didapatkan korelasi antara volume sinus ethmoid dengan usia.
\end{abstract}

Kata Kunci: CT scan sinus paranasalis, luas lamina papyracea, volume sinus ethmoid

Correspondence: Wahyuni. Department of Radiology Faculty of Medicine Universitas Hasanuddin Makassar, Jalan Perintis Kemerdekaan KM. 11, Makassar, Sulawesi Selatan, 90245 Tel. 08114801253 / (041) 581666Email:Mutaqwiyah@gmail.com

DOI: http://dx.doi.org/10.21776/ub.jkb.2020.031.01.6 


\section{INTRODUCTION}

Lamina papyracea (LP) is the weakest point of the orbital medial wall, which forms the connecting line between the paranasal sinuses and the orbit (1). Lamina papyracea articulates with the orbital plates of the superior frontal bone, maxillary and orbital processes of the inferior palatine bone, anterior lacrimal bone and posterior sphenoid (2). Precise knowledge of LP localization according to inferior nasal turbinate (INT) attachment to the lateral nasal wall is essential to avoid orbital penetration (3). As a consequence of LP penetration, periorbital ecchymosis or emphysema, venous orbital hematoma, medial rectus injury, and blindness can occur. During Endoscopic Sinus Surgery (ESS) that is important for the treatment of chronic rhinosinusitis and removal of sinonasal pathology, accidental LP injuries can occur $(3,4)$. Shigeta et al., reported the prevalence of LP injuries in their prospective study was $5.8 \%(1,5)$. Recognizing CT images from normal LP anatomy allows assessment on the targets of ESS and reconstructive surgery, including careful planning, the use of additional surgical approaches, efficient clearance of ethmoid air cells on LP, avoiding injury, and obtaining the exact dimensions of the implant (6).

Paranasal sinuses are a series of cavities that surround the nasal cavity (7). The main characteristics of paranasal sinuses are pneumatics, which have complex and varied anatomy $(8,9)$. Significant differences are considered to present in sinuses between individuals, even for the same individual, between the right and left sides of the sinuses (10). The variability in the size and shape of the paranasal sinuses is important in the FESS procedure (11). The ethmoid sinuses are important in the function of the sinus system because the paranasal sinuses drainage pathway can be through or adjacent to the lateral wall. The dimensions of ethmoids are important parameters in FESS $(12,13)$. In addition, it is necessary to have a good index, which correlates well with the volume. At present, the recognition of axial, sagittal, and coronal planes using computed tomography (CT) has allowed a more precise assessment of the structure of the ethmoid sinuses (8).

Paranasal sinuses computed tomography (CT) imaging has become a standard of care for preoperative planning (14). Helical CT allows for rapid acquisition and multiplanar reform. With the advent and the regular use of image guidance for intraoperative anatomical verification, images are recommended to be saved in a format accepted by the system when special preoperative imaging is performed. The image guidance system allows the surgeon to visualize CT images in all three imaging fields during FESS (15).

Based on the description above, the importance of knowing the breadth of the lamina papyracea and the ethmoid sinuses volume before doing the FESS made this research significant to conduct.

\section{METHODS}

\section{Research Design}

This study was a descriptive study that aimed to determine the lamina papyracea area and ethmoid sinuses volume in patients undergoing paranasal sinuses CT scan in preparation for FESS performed at the Radiology Department of Hasanuddin University General Hospital in Makassar in January to August 2019. The research variables consisted of independent variables (age and gender) and dependent variables (the lamina papyracea area and ethmoid sinuses volume). The study population was patients who were referred to the Radiology Department of UNHAS Hospital Makassar for a paranasal sinuses CT scan. Samples were all patients who meet the study criteria.

\section{Data Collection Methods}

This study was approved by the Health Research Ethics Committee of Faculty of Medicine, Hasanuddin University, Makassar, Number 533/UN4.6.4.5.31/PP36/2019. Data on the identities of patients who met the inclusion criteria were collected. The CT scan used was a high speed, dualsource CT scan, with a slide thickness of $0.6 \mathrm{~mm}$ axial slices and coronal reformatted. Then, the anteroposterior length of the LP, the anterior height of the LP, and the posterior height of the LP were measured and followed by calculating the breadth LP using the trapezium formula. The volume of the right and left, also the total volume of ethmoid sinuses were also measured. The results of the study were recorded in the research format sheet and then analyzed. The results were presented in the forms of tables and graphs.

\section{Data Analysis Techniques}

All data obtained were recorded in the research data form, grouped according to the purpose and type of data, and processed using the Statistical Program Social Science Software (the $25^{\text {th }}$ version SPSS), namely the Tindependent test and the Mann-Whitney test.

\section{RESULTS}

A number of 103 samples that met the inclusion criteria were obtained. Figure 1 shows an example of the measurement of lamina papyracea, and Figure 2 shows an example of the measurement of ethmoid sinus volume.

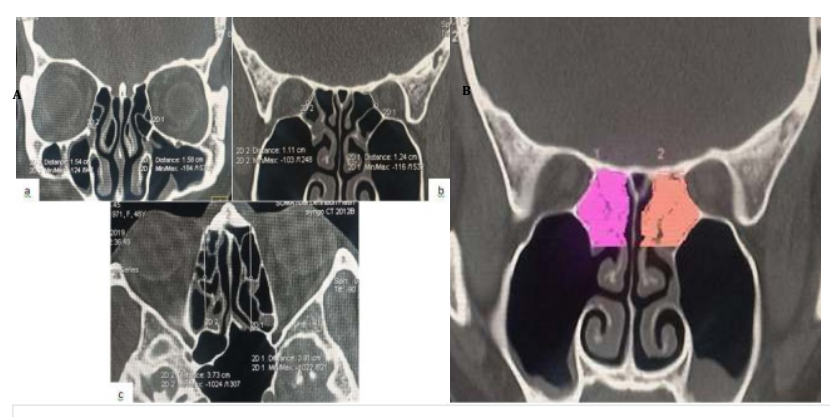

Figure 1. Example of lamina papyracea measurement and ethmoid sinuses

Note:

A. The anterior height of the coronal section (a), the posterior height of the coronal section (b), and the anteroposterior length of the axial section (c) of the right and left lamina papyracea of paranasal sinuses CT scan.

B. The right and left ethmoid sinuses volume on a CT scan of the paranasal sinuses in the coronal section.

Table 1 shows that the area of lamina papyracea do not show significant differences both in the left or fight side between female and male. The similarity between male and female was also found in each measurement indicator. 
Table 1. Distribution of minimum, maximum, mean, and SD values of the lamina papyracea (LP) by gender

\begin{tabular}{|c|c|c|c|c|c|c|c|c|c|c|}
\hline & \multirow[b]{2}{*}{ Measurement } & \multicolumn{3}{|c|}{ Males $(n=41)$} & \multirow[b]{2}{*}{ SD } & \multirow[b]{2}{*}{ Min } & \multicolumn{2}{|c|}{ Females $(n=62)$} & & $\mathbf{P}$ \\
\hline & & Min & Max & Mean & & & Max & Mean & SD & \\
\hline \multirow[t]{4}{*}{ Right } & Anteroposterior length of LP (cm) & 2.99 & 4.23 & 3.67 & 0.29 & 2.96 & 4.27 & 3.63 & 0.32 & $0.46^{*}$ \\
\hline & Anterior height of LP $(\mathrm{cm})$ & 1.27 & 2.17 & 1.74 & 0.18 & 1.20 & 2.37 & 1.72 & 0.24 & $0.61^{* *}$ \\
\hline & Posterior height of $\mathrm{LP}(\mathrm{cm})$ & 1.07 & 2.08 & 1.46 & 0.13 & 1.11 & 1.70 & 1.37 & 0.23 & $0.48^{*}$ \\
\hline & Breadth of $L P\left(\mathrm{~cm}^{2}\right)$ & 4.27 & 7.84 & 5.61 & 0.81 & 4.29 & 7.42 & 5.61 & 0.78 & $0.08^{* *}$ \\
\hline \multirow[t]{4}{*}{ Left } & Anteroposterior length of $\mathrm{LP}(\mathrm{cm})$ & 2.93 & 4.26 & 3.66 & 0.30 & 2.96 & 4.23 & 3.63 & 0.30 & $0.71^{*}$ \\
\hline & Anterior height of LP (cm) & 1.25 & 2.26 & 1.77 & 0.19 & 1.32 & 2.44 & 1.72 & 0.23 & $0.25^{*}$ \\
\hline & Posterior height of $L P(\mathrm{~cm})$ & 1.07 & 2.22 & 1.48 & 0.14 & 1.07 & 1.78 & 1.40 & 0.20 & $0.05^{* *}$ \\
\hline & Breadth of LP $\left(\mathrm{cm}^{2}\right)$ & 4.00 & 7.69 & 5.95 & 0.82 & 3.88 & 9.99 & 5.81 & 0.88 & $0.36 * *$ \\
\hline
\end{tabular}

Note:n: number, *: Mann-Whitney test, **: Independent T-test

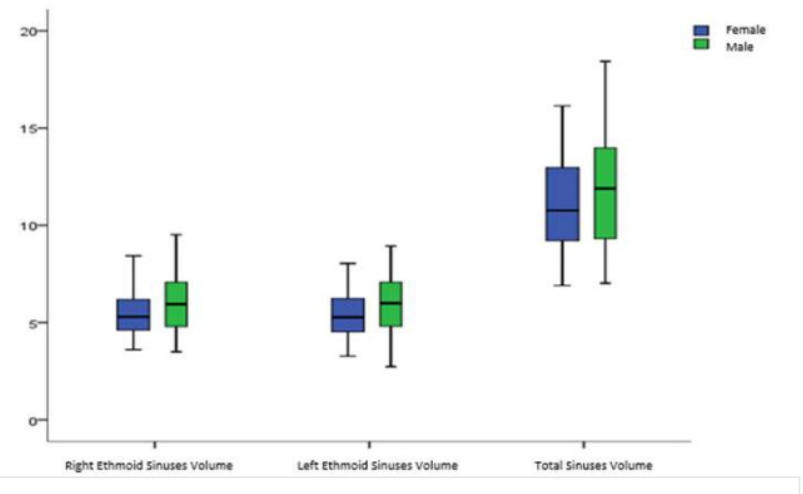

Graph 1. Boxplot graph of ethmoid sinuses volume by gender

Graph 1 shows the distribution of the volume of right ethmoid sinus, left ethmoid sinus, and total sinus volume based on gender, which reveals that the volume of ethmoid sinuses in males is greater than in females. For example, in male, the median volume of the right ethmoid sinuses was $6.06 \mathrm{~cm}^{3}$ higher when compared to the female $\left(5.47 \mathrm{~cm}^{3}\right)$.

Table 2 shows the distribution of the breadth right and left lamina papyracea based on age. No strong and significant correlation was found between age and the breadth right lamina papyracea $(p=0.10)$ as well as the breadth left lamina papyracea $(p=0.33)$. Different age groups does not show differences in the breadth of lamina papyracea both in the left and right sides.

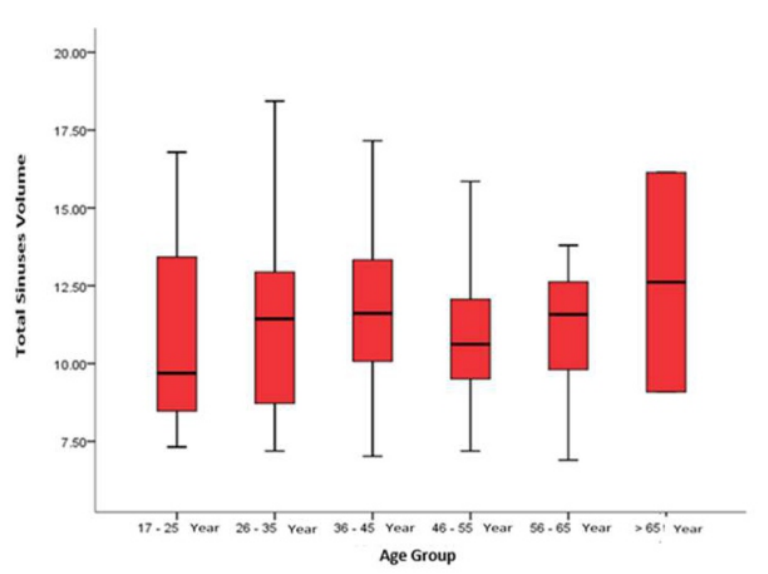

Graph 2. Boxplot graph of the distribution of ethmoid sinuses total volume $\left(\mathrm{cm}^{3}\right)$ by age

Graph 2 shows the distribution of ethmoid sinuses total volume by age. Based on age, the average ethmoid sinuses

Table 2. Distribution of minimal, maximum, mean and SD values of the breadth of lamina papyracea (LP) by age

\begin{tabular}{|c|c|c|c|c|c|c|c|c|c|c|c|}
\hline \multirow[b]{2}{*}{ Age } & \multicolumn{5}{|c|}{ The breadth of right LP } & \multicolumn{6}{|c|}{ The breadth of left LP } \\
\hline & $\mathbf{n}$ & $\begin{array}{l}\text { Min } \\
\left(\mathrm{cm}^{2}\right)\end{array}$ & $\begin{array}{l}\text { Max } \\
\left(\mathrm{cm}^{2}\right)\end{array}$ & $\begin{array}{l}\text { Mean } \\
\left(\mathrm{cm}^{2}\right)\end{array}$ & SD & $\mathbf{P}$ & $\begin{array}{l}\text { Min } \\
\left(\mathrm{cm}^{2}\right)\end{array}$ & $\begin{array}{l}\text { Max } \\
\left(\mathrm{cm}^{2}\right)\end{array}$ & $\begin{array}{l}\text { Mean } \\
\left(\mathrm{cm}^{2}\right)\end{array}$ & SD & $\mathbf{P}$ \\
\hline $17-25$ & 19 & 4.29 & 7.18 & 5.50 & 0.76 & 0.10 & 4.25 & 7.13 & 5.86 & 0.80 & 0.33 \\
\hline $26-35$ & 22 & 4.27 & 7.33 & 5.67 & 0.81 & & 4.00 & 7.69 & 5.68 & 0.73 & \\
\hline $36-45$ & 26 & 4.75 & 7.84 & 5.94 & 0.88 & & 4.55 & 7.62 & 5.91 & 0.66 & \\
\hline $46-55$ & 23 & 4.46 & 6.98 & 5.53 & 0.74 & & 3.88 & 9.99 & 5.78 & 1.21 & \\
\hline $56-65$ & 11 & 4.57 & 6.95 & 6.09 & 0.70 & & 5.36 & 7.92 & 6.38 & 0.69 & \\
\hline$>65$ & 2 & 5.74 & 6.46 & 6.10 & 0.50 & & 5.21 & 5.73 & 5.47 & 0.36 & \\
\hline
\end{tabular}

Note: $n$ : amount.

Source: Primary data. 
volume is almost the same. Although not significant, the median of total volume of ethmoid sinuses in age 17-25 was lower $\left(9.94 \mathrm{~cm}^{3}\right)$ when compared to the other elder age group 26-35 year $\left(11.41 \mathrm{~cm}^{3}\right)$, 36-45 year $\left(11.07 \mathrm{~cm}^{3}\right)$, $56-65$ year $\left(11.71 \mathrm{~cm}^{3}\right)$, > 65 year $\left(12.61 \mathrm{~cm}^{3}\right)$.

\section{DISCUSSION}

The results of this study are in line with the research conducted by Açar, et al. (2018), which measured the average values of the anteroposterior length, anterior height, posterior height, and the area lamina papyracea (1). Although statistically insignificant, there is a tendency of a greater size of lamina papyracea in males than in females. whereas for the average area of lamina papyracea in this study is the same as the study conducted by Açar et al., (1). Based on the analysis, the areas of the right and left lamina papyracea do not correlate with age. The average of lamina papyracea area in males tends to be greater than in females and the average of lamina papyracea area is almost the same based on age.

Lamina papyracea (LP) is the weakest point of the orbital medial wall and perforation of the LP result in a risk of periorbital ecchymosis or emphysema, venous orbital hematoma, medial rectus injury, and blindness can occur $(1,6)$. During endoscopic sinus surgery, the lower limit of the middle meatal antrostomy was the inferior nasal turbinate attachment to the lateral nasal wall. If during pre-operative periode the LP location related to this limit can be identified, the LP penetration, which was the most frequent iatrogenic complication $(5 \%)$ will be prevented (3). The comprehensive knowledge of the normal anatomy of the LP allows safer and more effective sinus surgery and is essential for sufficient orbital reconstruction with proper implant, and also recreation of natural slope at the IMS. So, the success of surgical technique increases, and the best outcome can be provided.

\section{REFERENCES}

1. Açar G, Büyükmumcu $M$, and Güler İ. Computed Tomography-Based Analysis of the Lamina Papyracea Variations and Morphology of the Orbit Concerning Endoscopic Surgical Approaches. Brazilian Journal of Otorhinolaryngology. 2019; 85 (5): 551-559.

2. Johan F. Open Access Atlas of Otolaryngology, Head \& Neck Operative Surgery. (Online) 2017. http://www.entdev.uct.ac.za/

3. Herzallah IR, Marglani OA, and Shaikh AM. Variations of Lamina Papyracea Position from the Endoscopic View: A Retrospective Computed Tomography Analysis. International Forum of Allergy \& Rhinology. 2015; 5(3): 263-270.

4. El-Anwar MW, Khazbak AO, Eldib DB, and Algazzar HY. Lamina Papyracea Position in Patients with Nasal Polypi: A Computed Tomography Analysis. Auris Nasus Larynx. 2018; 45(3): 487-491.

5. Shigeta Y, Okushi T, Yoshikawa M, et al. Endoscopic Sinus Surgery Complications a Prospective Multicenter Study. Nihon Jibiinkoka Gakkai Kaiho. 2012; 115(1): 22-28.
Research conducted by Emirzeoglu et al., as well as Bulescu et al., found that the average volume of the right and left ethmoid sinuses also ethmoid sinuses total by gender are almost the same $(8,16)$, this study found a slight difference, that the ethmoid sinus volume is different by gender. Statistically, there is a correlation between the volume of the right ethmoid sinus and gender, that males have a greater volume than females, but for the left sinus ethmoid volume and ethmoid sinuses total volume, there is no correlation between males and females. The volume in males tends to have a greater size than in females. Our finding related to the total volume of ethmoid sinuses by age is almost the same in the study of Emirzeoglu et al., and Bulescu et al., but this study shows a larger volume of ethmoid sinus. The ethmoid sinus volume in men tends to be greater than that of women and the average ethmoid sinus volume is almost the same based on age.

The ethmoid sinus is probably the most interesting, controversial and important of the paranasal sinuses. From an embryologic point of view, the ethmoid is different from all other paranasal sinuses. In anatomical terms, the ethmoid is also different from other paranasal sinuses, since its cells are separated by very thin bony lamellae, while the walls of other sinuses are more rigid and robust. Due to this important characteristic of ethmoid cells, it is said that one cell may outgrow the ones next to it and force them in another direction or limit their expansion (17). The volumetric value is the key to establishing an objective definition of hypoplasia or sinus atelectasis. This indicator is useful to consider normal values and clinical indices in the diagnostic approach to sinus pathologies such as sinusitis or sinus dysmorphism. Nowadays, exact knowledge of the paranasal sinus anatomy is very important for functional endoscopic sinus surgery and it is essential for a preoperative evaluation (18). Finding of this research indicate that knowing the anatomical variation of the lamina papyracea and ethmoid sinus based on age and gender can help clinicians in performing surgery.

6. Lee JE, Lee JJ, Lee SU, et al. CT-Based Morphological Analysis of Isolated Inferior and Medial Blow-out Orbital Fractures in Korean Adults. Orbit. 2015; 34(6): 303-308.

7. Khan MK. Essential Otolaryngology Head \& Neck Surgery, 10th Edn. K J Lee, Ed. McGraw-Hill, 2012. ISBN 9780071761475 pp 117 Price (paperback) $£ 74.99 \$ 119.95$. The Journal of Laryngology \& Otology. 2013; 127(3): 330.

8. Bulescu IA, Munteanu O, Stanciulescu R, et al. Computed-Tomography Volumetric Study of the Ethmoid Labyrinth. Romanian Journal of Rhinology. 2017; 7(27): 181-184.

9. Cashman EC, MacMahon PJ, and Smyth D. Computed Tomography Scans of Paranasal Sinuses before Functional Endoscopic Sinus Surgery. World Journal of Radiology. 2014; 6(8): 567-583.

10. Hiyama T, Shiigai $M$, Masumoto $T$, Minami M, Tsukuba, and Ibaraki/JP. The Ethmoid Bone: Clinical Imaging Anatomy from an Embryological Point of View. European Society of Radiology. 2013; C-2208: 1-76.11. Reddy UDMA and Dev B. Pictorial Essay: Anatomical Variations of Paranasal Sinuses on Multidetector Computed Tomography-How Does It 
Help FESS Surgeons? Indian Journal of Radiology and Imaging. 2012; 22(4): 317-324.

12. Gabriel $\mathrm{OH}$, Kenneth O, Bright O, and Sagbodje DE. Morphology and Anatomical Variations of the Ethmoidal Sinus in Adult Nigerians. International Scholars Journals. 2017; 4(2): 95-100.

13. Gupta AK, Bansal S, and Sahini D. Anatomy and Its Variations for Endoscopic Sinus Surgery. Clinical Rhinology. 2012; 5(2): 55-62.

14. Schembri N, Gatt AS, Ellul D, Brunton J, and Dundee/UK. Computed Tomography Road Map of the Paranasal Sinuses for Treatment Planning. European Society of Radiology. 2013; C-2607: 1-21.

15. O'Brien WT Sr, Hamelin S, and Weitzel EK. The Preoperative Sinus CT: Avoiding a "CLOSE" Call with Surgical Complications. Radiology. 2016; 281(1): 10-
21.

16. Emirzeoglu M, Sahin B, Bilgic S, Celebi M, and Uzun A. Volumetric Evaluation of the Paranasal Sinuses in Normal Subjects Using Computer Tomography Images: A Stereological Study. Auris Nasus Larynx. 2006; 34(2): 191-195.

17. Marquez S, Tessema B, Clement PA, and Schaefer SD. Development of the Ethmoid Sinus and Extramural Migration: The Anatomical Basis of this Paranasal Sinus. The Anatomical Record: Advances in Integrative Anatomy and Evolutionary Biology. 2008; 291(11): 1535-1553.

18. Fernandez JMS, Escuredo JAA, Del Rey AS, and Montoya FS. Morphometric Study of the Paranasal Sinuses in Normal And Pathological Conditions. Acta Oto-Laryngologica. 2000; 120(2): 273-278 